\title{
IDENTIFICATION OF MICROBES ANTAGONISTIC AGAINST Fusarium oxysporum ISOLATED FROM RHIZOSPHERE ZONE OF WATERMELON
}

\author{
IDENTIFIKASI MIKROBA ANTAGONIS Fusarium oxysporum \\ YANG DIISOLASI DARI RHIZOSFER TANAMAN SEMANGKA
}

\author{
Anak Agung Ngurah Nara-Kusuma ${ }^{1}$, Yan Ramona ${ }^{1,2 *}$, Meitini Wahyuni Proborini ${ }^{1}$ \\ 1) Postgraduate Study Program of Biology, Udayana University \\ 2) Integrated Laboratory for Biosciences and Biotechnology, Udayana University \\ *Email: yan_ramona@yahoo.com ; yan_ramona@unud.ac.id
}

Diterima 6 Juli 2016 Disetujui 18 Desember 2018

\begin{abstract}
This research was aimed to isolate and identify microbes which antagonistic against Fusarium oxysporum, the causative agent of vascular wilt in watermelon plants. The antagonistic microbes were isolated from soil samples collected from rhizosphere of watermelon farm located at west Sanur village, South Denpasar, Bali. Isolation of fungi and bacteria were conducted on potato dextrose agar medium (PDA) and nutrient agar medium (NA), respectively. Fungal isolates were then observed under light microscope for its morphological characteristics before identification using a reference book. Bacterial isolates were characterized using various tests, such as gram stain reaction, existence of endospores, catalase reaction, and ability to ferment various sugars. Their characteristics were then compared with those described in a reference book. Two fungal species (Trichoderma harzianum and Trichoderma viride) and two bacterial antagonists (Pseudomonas sp. and Bacillus sp.) were found to have potential to be developed as biocontrol agents to inhibit the growth of F. oxysporum.
\end{abstract}

Keywords: Bacillus sp., Pseudomonas sp., Trichoderma harzianum, Trichoderma viride, Bali, Watermelon

\section{INTISARI}

Penelitian ini bertujuan untuk mengisolasi dan mengidentifikasi mikroba yang bersifat antagonis terhadap Fusarium oxysporum yaitu penyebab penyakit layu vaskular pada tanaman semangka. Mikroba antagonis diisolasi dari sampel tanah yang diambil dari rhizospher tanaman semangka yang ditanam di perkebunan yang berlokasi di desa Sanur Barat, Denpasar Selatan, Bali. Isolasi fungi dilakukan pada dextrose agar medium (PDA) dan isolasi bakteri dilakukan pada nutrient agar medium (NA). Isolat fungi diamati dengan microskop cahaya untuk mengetahui ciri-ciri morfologi sebelum diidentifikasi menggunakan buku reference. Isolat bakteri dikarakterisasi menggunakan beberapa uji, meliputi, reaksi pewarnaan gram reaksi katalase dan kemampuan untuk melakukan fermentasi terhadap gula. karakteristik bakteri yang diamati kemudian dibandingkan dengan karakteristik bakteri yang tertera dalam buku reference. Dua spesies fungi (Trichoderma harzianum dan Trichoderma viride) dan dua spesies bakteri (Pseudomonas sp. dan Bacillus sp.) yang berpotensi untuk dikembangkan menjadi agen biokontrol penghambat pertumbuhan $F$. oxysporum berhasil diisolasi dalam penelitian ini.

Kata kunci: Bacillus sp., Pseudomonas sp., Trichoderma harzianum, Trichoderma viride, Bali, Semangka

\section{INTRODUCTION}

According to report Indonesian Statistical Agent in 2011, watermelon production in Indonesia reached 474,327 tons in 2009. However, production of this fruit decreased sharply in 2010 where its production was only 348,631 tons. The main cause of this decrease was attributed by vascular wilt due to Fusarium oxysporum infection (Budiastuti et al., 2012). This fungus is a soil borne pathogen causing many severe problems in many agricultural crops, including water melon. Plants infected by this fungus will show specific characteristics, such as stem rot with browny color and drying leaves. Until recently, watermelon farmers in west Sanur area rely only on the use of chemical-based fungicides to cope with this infection. Long term application of these fungicides has been claimed to have negative impact on ecosystems due to its long half-life (Djunaedi, 2009).

Based on the above background, a new and more environmentally friendly method, such as the use of natural enemy for this pathogen needs to be developed. Therefore in this research, microbes antagonistic against $F$. oxysporum were isolated from rhizosphere zone of watermelon farm located in West Sanur area. The main 
objective of this research was to obtain potential antagonist isolates to be used to fight $F$. oxysporum infection in watermelon plants.

\section{MATERIALS AND METHODS}

\section{Sample collection}

Fungal and bacterial antagonists were isolated from soils collected randomly from rhizosphere zone of watermelon farm in west Sanur area. Soil samples (100 g each) were aseptically collected from 6 locations in this area, placed in plastic bags, and transported to Microbiology Lab in School of Biology, Udayana University where isolation of microbes antagonistic against Fusarium oxysporum was conducted.

\section{Isolation of antagonists}

Fungal and bacterial antagonists were isolated by applying dilution and spread method as specified in Ramona and Line (2002), Ramona (2005) Suryanti et al. (2013), and Wulansari et al. (2015). Samples were diluted up to dilution rate of $10^{-6}$ and spread on potato dextrose agar medium (PDA) for fungal isolation or on nutrien agar medium (NA) for bacterial isolation. All inoculated media were incubated at ambient temperature for 2-5 days until bacterial or fungal colonies grew. Colonies that showed antagonistic activities against $F$. oxysporum in in vitro dual culture assays were isolated and identified at least up to genus level.

\section{Identification of bacterial and fungal antagonists}

Fungi and bacteria that showed antagonistic activities against $F$. oxysporum in the in vitro assays were identified up to genus or species level when necessary based on their morphological and physiological characteristics. Fungal isolates were observed under a light microscope for their hypha morphology, conidiophore, their spore structures, and colour on PDA. Their characteristics were then compared with that specified in a reference book of Fungi and Food Spoilage (Pitt and Hocking, 1997). For bacterial identification, their characteristics observed included gram stain reaction, endospore existence, catalase reaction, ability to ferment various sugars (glucose, lactose, maltose and sucrose), reaction on indol, and motility on SIM medium. The characteristics of each bacterial isolate were then compared with that specied in reference book of Bergey's Manual of Determinative Bacteriology $9^{\text {th }}$ Edition (Holt et al., 1994).

\section{RESULTS}

Two potential fungal and two bacterial antagonists were successfully isolated in this project. The microscopic and macroscopic (visualized with a Yazumi light microscope with $400 \mathrm{x}$ magnification) characteristics of T. Harzianum and $T$. viride at 5 days of aged on PDA medium are shown in Figure 1 and the microscopic characteristic of these two bacterial isolate is shown in Figure 2.

\section{DISCUSSION}

The two potential fungal antagonists were identified as Trichoderma harzianum and Trichoderma viride. The mycelium of the Trichoderma harzianum was initially white, and as a function of time it changed to green with grey pigmentation. Their Fialid grew on each branch tip where their clustered konidia with pale green were found. The size of their konidia, the length of their fialid, and the diameter of their hyphae ranged 2.63-3.07 $\mu \mathrm{m}, 7.28-8.54$ $\mu \mathrm{m}$, and 2.67-3.71 $\mu \mathrm{m}$, respectively. Those characteristics matched with those specified in the identification reference book of Fungi and Food Spoilage (Pitt and Hocking, 1997). While the Trichoderma viride initially had pale green colonies and then changed into dark green. Their konidia are round and green, and located on the tips of their fialid. The size of their konidia, the length of their fialin, and the diameter of their hyphae ranged from 3.58 to $5.46 \mu \mathrm{m}$, from 7.62 to $8.46 \mu \mathrm{m}$, and from 2.60 to $2.74 \mu \mathrm{m}$, respectively. According to Pitt and Hocking (1997), both T. viride and T. harzianum are morphologically similar. The difference between them is the size of their konidia, where the size of T. viride konidia is bigger (ranging from 3.5 to $5.5 \mu \mathrm{m}$ ) than that of $T$. harzianum. The microscopic and macroscopic (visualized with a Yazumi light microscope with $400 \mathrm{x}$ magnification) characteristics of T. harzianum and T. viride at 5 days of aged on PDA medium are shown in Figure 1.

$T$. harzianum and $T$. viride successfully isolated in this project were found to dominate the six locations of sampling points in the watermelon farm, in west Sanur area. This results is in line with that reported by Otadoh (2011) who stated that Trichoderma spp. are saprophytic fungi widely spread in soil samples. This type of fungi can grow rapidly in the rhizosphere zone of plants (Saba et al., 2012). When grown on a mediun in vitro, their growth is characterizes by green konidia (Steyaert, 2007).

Fungi Trichoderma spp. has ability to produce cell wall degrading enzymes, such as cellulase (Raut et al., 2014), chitinase (Sharma et al., 2012), and glucanase (Saba et al., 2012). These enzymes help their hyphae to penetrate lumen and assimilate the cell wall of fungal pathogensFurthermore, Sharma et al. (2012), Hassan et al. (2013) and Benitez et al. (2004) reported that Trichoderma spp. also has the ability to produce antibiotics, such as harzianic acid, alamethicins, tricholin, peptaibols, alkil piron, massoilactone, viridin, gliovirin, glisoprenins, heptelidic acid, inhibiting the growth of other fungi around them. 

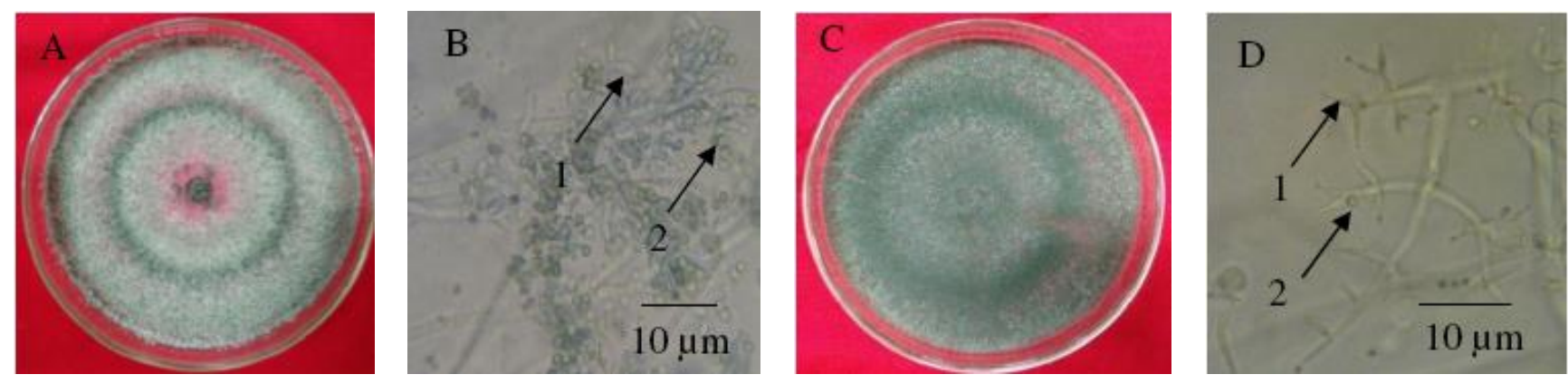

Figure 1. Macroscopic and microscopic characteristics of T. harzianum (A and B) and T. viride (C and D). Their Fialid and Konidia are shown by numbers 1 and 2, respectively.
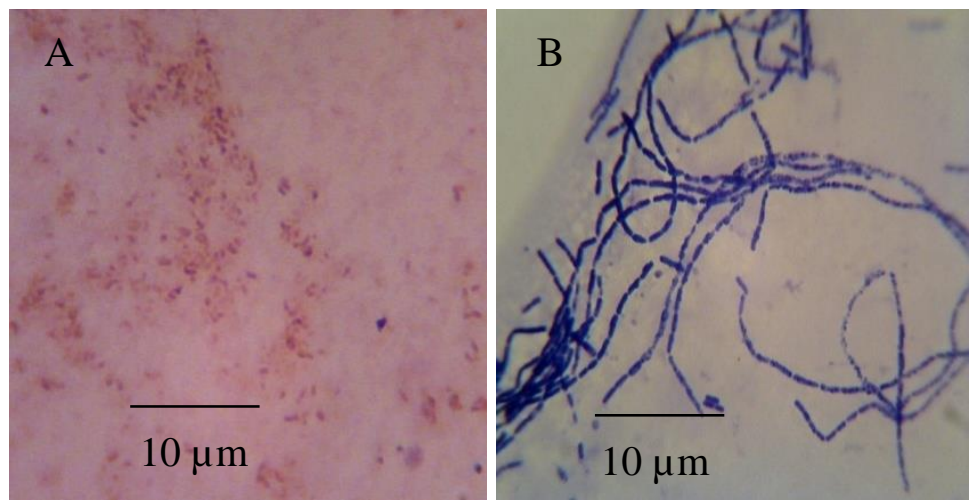

Figure 2. Microscopic characteristic of Pseudomonas sp. (A) and Bacillus sp. (B) observed under a light microscope (Yazumi) with magnification of $1000 x$

In addition to hydrolitic enzymes and antibiotics, some species of Trichoderma also produce siderophores for chelating $\mathrm{Fe}^{3+}$ ions in the soil so that the availability of these ions is limited for fungal pathogens (Benitez et al., 2004). Due to those characteristics, many species of Trichoderma spp. have been developed as biocontrol agents to control infections of Fusarium (Ojha and Chatterjee, 2012), Rhizoctonia (Seema and Devaki, 2012), and Phytium (Raut et al. 2014).

This research showed two bacterial antagonists were successfully isolated in this and they were identified as Pseudomonas sp. and Bacillus sp., based on the characteristics specified in the reference book of Bergey's Manual Determinative Bacteriology $9^{\text {th }}$ Edition (Holt et al., 1994). Pseudomonas sp. isolate has greenish yellow pigment when grown on a solid medium in vitro. Other characteristics of this isolate observed in this research were Gram negative with cell size ranging from 0.86 to $1.91 \times 0.2$ to $0.67 \mu \mathrm{m}$, no endospore, catalase possitive, ferments sugars (glucose, maltose, and sucrose), motile on SIM medium, unable to ferment laktosa, and showed neative result for indol test. Whilst, Bacillus sp. isolate showed some characteristics, such as Gram possitive, chain cells with size of 2.44 to $2.90 \times 0.61$ to $1.73 \mu \mathrm{m}$, produced endospore, catalase possitive, fermented sugars (glucose, maltose, and sucrose), motile on SIM medium, negative indol test, and did not ferment lactose. The microscopic characteristic of these two isolate is shown in Figure 2.

In the in vitro bioassays, these two bacterial antagonists inhibited the growth of Fusarium oxysporum (the causative agent of wilt in watermelon plant). The main cause of this inhibition was inconclusive and need to be further elucidated. Although it was inonclusive, some researchers reported that inhibition of Pseudomonas or Bacillus isolates may be due to sideropore production (Karimi et al., 2012), antibiosis (Sallam et al. 2013), competition (Jenifer et al., 2013), or other toxic compounds, such as HCN (Chaur and Lo, 1998). Ozaktan et al. (2015) and Vijayaraghavan and Vincet (2012) stated that antibiosis mechanism by Pseudomonas sp. and Bacillus sp. on fungal pathogens can happen through production of hydrolitic enzimes, such as cellulase, glucanase and chitinase. Toua et al. (2013) and Chaur and Lo (1998) reported that Pseudomonas sp. are also capable to produce antibiotics, such as phenazins, pyrrolnitrine and 2,4-diacetylphloroglucinol, in addition to the above hydrolitic enzymes.

\section{CONCLUSION}

Based on the morphological and physiological characteristics of the isolates, the two fungal and bacterial isolates were identified as T. harzianum, T. viride and Pseudomonas sp. and Bacillus sp. Those microbes appeared to be potential for bio control agent development to control the causative agent of wilt vascular disease in watermelon farm. 


\section{REFERENCES}

Badan Pusat Statistik. 2013. Produktivitas Tanaman Hortikultura Menurut Provinsi 2008-2011. BPS dan Dirjen. Hortikultura.

Benitez, T., A. Rincon, M.C. Limon and A. Codon. 2004. Biocontrol mechanism of Trichoderma strains. Intl. J.Microbiology 7:249-260.

Budiastuti, K., E.T. Tondok dan S. Wiyono. 2012. Causal agents of wilting Disease on Watermelon in Karawang, West Java. J. Fitopatologi Indonesia 8(4): 89-96.

Chaur and T. Lo. 1998. General mechanisms of action of microbial biocontrol agents. Plant Pathology Bull. 7:155-166.

Djunaedi, A. 2009. Biopestisida sebagai pengendali organisme pengganggu tanaman (OPT) yang ramah lingkungan. Embryo 6 (1):88-95.

Hassan, R. Simon, Gowen, B. Pembroke. 2013. Use of Trichoderma hamatum for biocontrol of lentil vascular wilt disease: efficacy, mechanisms of interaction and future prospects. J. Plant Protection Res 53(1): 13-26.

Holt, J.G., N.R. Krieg, P.H.A. Sneath, J.T. Staley and S.T. William. 1994. Bergey`s Manual of Determinative Bacteriology $9^{\text {th }}$ Edition. USA : Lippincott Williams and Wilkins.

Jenifer, M. R. A., A. Reena, O.S. Aysha, S. Valli, P. Nirmala, P. Vinothkumar. 2013. Isolation of siderophore producing bacteria from rhizosphere soil and their antagonistic activity against selected fungal plant pathogens. Intl. J. Curr. Microbiology App. Sci. 2(1): 59-65.

Karimi, K., J. Amini, B. Harighi, B. Bahramnejad. 2012. Evaluation of biocontrol potential of Pseudomonas and Bacillus Spp. against Fusarium wilt of chickpea. AJCS 6(4): 695-703.

Ojha, S. and N.C. Chatterjee. 2012. Induction of resistance in tomato plants against Fusarium oxysporum f.sp. Lycopersici mediated through salicylic acid and Trichoderma harzianumi. J. Plant Protection Res. 52 (2): 220-225.

Otadoh, J.A., A. Sheila, Okoth, J. Ochanda, J.P. Kahindi. 2011. Assessment of Trichoderma isolates for virulence efficacy on Fusarium oxysporum f.sp. phaseoli. Tropical and Subtropical Agroecosystems 13: 99-107.

Ozaktan, H, Çakır, A. Gül, L. Yolageldi, A. Akköprü, Fakhraei, Akbaba. 2015. Isolation and evaluation of endophytic bacteria against Fusarium Oxysporum f. sp. Cucumerinum infecting cucumber plants. Austin J. Plant Bio. 1 (1): 1-6.

Pitt, J.I. and A.D. Hocking. 1997. Fungi and food spoilage Vol. II, Ed. Pitt, J.I. and Hocking, A.D. London: Blackie Academic and Professional.

Ramona, Y. and M.A. Line. 2002. Potential for largescale production of a biocontrol fungus in raw and composted paper mill waste. Compost Science and Utilization. 10(1): 57-62.
Ramona, Y. 2003. Assessment of some antagonist to fungal plant pathogens development of methods for their large scale cultivation. Ph.D.Thesis, The University of Tasmania. Australia.

Raut, J., M. Calin, G. Vasilescu, M.B. Doni, T. Sesan, L. Jecu. 2014. Effect of non volatile compounds of Trichoderma Spp. against Fusarium graminearum, Rhizoctonia solani and Pythium ultimum. Scientific Bull.Series F. Biotechnologies 18: 178-181.

Saba, Vibhash, Manisha, Prashant, Farhan, Tauseef. 2012. Trichoderma a promising plant growth stimulator and biocontrol agent. Mycosphere 3(4): 524-531.

Sallam, N.A., S.N. Riad, M.S. Mohamed, A.S. El-eslam. 2013. Formulations of Bacillus Spp. and Pseudomonas fluorescens for biocontrol of cantaloupe root rot caused by Fusarium Solani. J. Plant Protection Res. 53(3): 295300.

Seema and Devaki. 2012. In vitro evaluation of biological control agents against Rhizoctonia solani. J. Agric.l Tech. 8 (1): 233-240.

Sharma, Radheshyam, J. Arunabh and C.D. Ramesh. 2012. A brief review on mechanism of Trichoderma fungus use as biological control agents. Intl J. Innovations in BioSciences 2 (4): 200-210.

Steyaert, J.M. 2007. Studies on the regulation of conidiation in species of Trichoderma. (Thesis). Lincoln University.

Suryanti, I.A.P., Y. Ramona, M.W. Proborini. 2013. Isolation and identification of the causative agents of wilting and their antagonistics in potato plants cultivated in Bedugul, Bali. J. Biologi 17(2): 37-41.

Toua, D., M. Benchabane, F. Bensaid, R. Bakour. 2013. Evaluation of Pseudomonas fluorescens for the biocontrol of Fusarium wilt in tomato and flax. African J. Microbiology Res. 7(48): 5449-5458.

Vijayaraghavan, P and S.G.P. Vincent. 2012. Purification and characterization of carboxymethyl cellulase from Bacillus sp. isolated from a paddy field. Polish J.Microbiology 61(1): 51-55.

Wulansari, N.T. 2015. Upaya pengendalian penyebab penyakit busuk hitam pada tanaman brokoli (Brassica oleracea var. italica) dengan antagonisnya. (Tesis). Denpasar: Universitas Udayana. 